\title{
Penggunaan Non Speech Oral Motor Treatment (Nsomt) Sebagai Pendekatan Intervensi Gangguan Bunyi Bicara
}

\author{
Hafidz Triantoro Aji Pratomo ${ }^{*}$, Arif Siswanto ${ }^{2}$ \\ ${ }^{1,2}$ Jurusan Terapi Wicara, Poltekkes Kemenkes Surakarta \\ *Email: pratomo.hafidz@gmail.com
}

\begin{abstract}
Abstrack
Background : Non Speech Oral Motor Treatment's (NSOMT) is a collective term that require active and passive training of speech musculature (Lof \& Watson, 2008). Controversy of use this method was found in several publication. Researcher notes many questions about NSOMT efication. Aim of study is to gather information about utility NSOMT among Speech Therapist's in Central Java. Isssue of Evidence Based Practice (EBP)implementation was crucial to be answer. This study was to analyse use of NSOMT among central java clinicians who treat children with speech sound disorder. Methods: This study was conducted in March until July 2019. Total 146 speech therapist across Central Java was participated on this study. Data analysis used descriptive statistic and Spearman Rank. Results: 84,9\% speech therapist in Central Java used NSOMT to treat children who have speech sound disorder. Education level had a correlation with utility NSOMT in speech sound intervention (OR: 4.61; 95\%: 1.44-14.72; p: 0.010). Conclusions: The results suggested similar finding with survey was conducted before. Speech therapist needs to improve their knowledge about EBP and its implementation.
\end{abstract}

Keywords: non speech oral motor treatment, speech sound disorders, speech therapy

\section{PENDAHULUAN}

Non Speech Oral Motor Treatment (NSOMT) merupakan prosedur atau pendekatan yang dikenal berkaitan dengan penanganan gangguan bunyi bicara yang berbasis pada penekanan aspek motorik dan sensoris (Ruscello, 2008). NSOMT merupakan kumpulan metode dan Teknik yang bertujuan meningkatkan kualitas bicara klien (Lof \& Watson, 2008). Pendekatan ini merupakan pendekatan yang bertujuan meningkatkan aktivitas non bicara meliputi bibir, rahang, lidah, velum, laring, dan otot respirasi yang berkaitan dengan fisiologi dan mekanisme oral fasial. Aktivitas aktif meliputi penguatan otot, latihan pasif, dan stimulasi sensoris (McCauley et al., 2009). Meskipun cukup populer, pertanyaan tentang efektifitas penanganan gangguan bunyi bicara dengan NSOMT masih pertanyakan (Forrest, 2002). NSOMT dikenal efektif dalam meningkatkan kemampuan menelan.
Pendekatan ini signifikan diterapkan pada klien dengan permasalahan makan dan menelan. Stimulasi sensoris terbukti mampu meningkatkan kemampuan menelan (Clark, 2003). Ketika pendekatan ini diterapkan pada gangguan bunyi bicara, temuan telah menghasilkan hasil temuan pada dua sisi. Kontroversi muncul karena di satu sisi NSOMT efektif meningkatkan kualitas bicara dan satu sisi tidak efektif meningkatkan kualitas bicara (Muttiah et al., 2011). Perbedaan mekanisme antara proses makan dan menelan dengan mekanisme proses produksi bicara memunculkan pertanyaan mendasar tentang perbedaan dampak intervensi. NSOMT memiliki implikasi yang berlawanan apabila diterapkan pada klien dengan gangguan bunyi bicara (Mccauley et al., 2009).

Pertanyaan tentang efektifitas NSOMT pada penanganan gangguan bunyi bicara menunjukkan bahwa diskusi tentang Evidence Based Practice (EBP) 
merupakan komponen esensial. EBP memberikan gambaran bahwa NSOMT tidak memiliki dampak signifikan terhadap penanganan gangguan bunyi bicara (Lass \& Pannbacker, 2008; Lee \& Gibbon, 2011; Mccauley et al., 2009; Powell, 2008). Meskipun tidak memiliki level EBP yang kuat dalam sebagai metode intervensi, pendekatan ini merupakan pendekatan yang cukup popular digunakan terapis wicara dalam penanganan gangguan bunyi bicara.

Penelitian Lof \& Watson, (2008) dan Thomas \& Kaipa, (2015) menunjukkan sekitar $85 \%$ terapis wicara atau klinisi menggunakan pendekatan ini sebagai prosedur dalam meningkatkan kemampuan bicara klien dengan keluhan gangguan bunyi bicara. Penelitian menjadi komponen penting dalam pelaksanaan terapi wicara untuk peningkatan kualitas pelayanan terapi wicara (Dodd, 2007; Togher et al., 2011). Indonesia memiliki tantangan yang besar dalam penerapan EBP dalam pelayanan kesehatan (Turner, 2009).

Penerapan EBP dalam pelayanan terapi wicara memiliki hambatan dalam sumber literatur. Penelitian ini merupakan penelitian yang pertama kali dilakukan di Jawa Tengah dengan tema Penerapan NSOMT. Penelitian lain belum mengungkap bagaimana penggunaan NSOMT oleh Terapis Wicara di Jawa Tengah. Tujuan penelitian ini mengungkap gambaran penggunaan NSOMT dalam penanganan gangguan bunyi bicara di Jawa Tengah. Artikel ini bertujuan untuk mengetahui profil penggunaan NSOMT di Jawa Tengah. Pembahasan difokuskan pada prosentase penggunaan NSOMT, gambaran penggunaan NSOMT, gambaran penggunaan Non NSOMT, dan pendekatan intervensi yang dilakukan oleh Terapis Wicara di Jawa Tengah.

\section{METODE PENELITIAN}

Pengambilan data dilakukan pada pada bulan Maret - Juli 2019. Penelitian dilakukan di wilayah kerja Ikatan Terapis Wicara Wilayah Jawa Tengah. Ijin penelitian disetujui oleh Ketua Dewan Pengurus Ikatan Terapis Wicara Jawa Tengah yang selanjutnya kuesioner dibagikan ke seluruh Dewan Pengurus Cabang (DPC). Responden berasal dari enam DPC yakni Surakarta, Semarang, Magelang, Pekalongan, Pati, dan Banyumas.

Pengumpulan data dilakukan dengan metode survey. Instrumen berupa kuesioner yang dimodifikasi (Lof \& Watson, 2008; Thomas \& Kaipa, 2015). Instrumen penelitian terdiri dari empat bagian. Bagian pertama tentang informasi demografi responden. Bagian kedua berisi tentang informasi penggunaan NSOMT sebagai pendekatan intervensi gangguan bunyi bicara. Bagian ketiga memuat informasi tentang responden yang tidak menggunakan NSOMT sebagai pendekatan intervensi gangguan bunyi bicara. Bagian keempat berisi tentang jenis-jenis metode intervensi gangguan bunyi bicara. Setiap responden wajib mengisi bagian pertama. Bagi responden yang menggunakan NSOMT sebagai metode intervensi gangguan bunyi bicara akan mengisi bagian kedua dan keempat. Bagi responden yang tidak menggunakan NSOMT sebagai metode intervensi gangguan bunyi bicara akan mengisi bagian ketiga dan keempat.

Analisis data menggunakan aplikasi SPSS for Windows 24. Analisis statistik terdiri dari analisis statistik deskriptif dan analisis korelasi Spearman Rank. Analisis 
Deskriptif dilakukan untuk mengetahui gambaran responden penelitian. Analisis korelasi dilakukan untuk melihat korelasi antar variabel penelitian.

\section{HASIL PENELITIAN}

Responden yang mengembalikan angket berjumlah 146 orang. Informasi demografi terdiri dari wilayah keanggotan, jenis kelamin, pendidikan, tempat bekerja, pengalaman klinis, dan peminatan bidang garap.

Tabel 1. Data Demografi Responden

\begin{tabular}{|c|c|c|c|}
\hline \multicolumn{2}{|l|}{ Komponen Demografi } & \multirow{2}{*}{$\frac{\mathbf{N}=\mathbf{1 4 6}}{64}$} & \multirow{2}{*}{$\begin{array}{c}\% \\
43.8\end{array}$} \\
\hline Keanggotaan Dewan & Surakarta & & \\
\hline \multirow[t]{5}{*}{ Pengurus Cabang } & Semarang & 19 & 13 \\
\hline & Banyumas & 17 & 11.6 \\
\hline & Magelang & 14 & 9.6 \\
\hline & Pati & 19 & 13 \\
\hline & Pekalongan & 13 & 8.9 \\
\hline \multirow[t]{2}{*}{ Jenis Kelamin } & Perempuan & 117 & 80.1 \\
\hline & Laki-laki & 29 & 19.9 \\
\hline \multirow[t]{2}{*}{ Pendidikan } & Diploma III Terapi Wicara & 110 & 75.3 \\
\hline & Diploma IV Terapi Wicara & 36 & 24.7 \\
\hline \multirow[t]{6}{*}{ Tempat Bekerja } & Rumah Sakit Pemerintah & 48 & 32.9 \\
\hline & Rumah Sakit Swasta & 36 & 24.7 \\
\hline & Klinik & 28 & 19.2 \\
\hline & Pelayanan Mandiri & 12 & 8.2 \\
\hline & Sekolah Luar Biasa & 6 & 4.1 \\
\hline & Pelayanan Khusus Lain & 16 & 11 \\
\hline \multirow[t]{5}{*}{ Pengalaman Klinis } & Kurang Dari 5 Tahun & 101 & 69.2 \\
\hline & $6-10$ Tahun & 36 & 24.7 \\
\hline & $11-15$ Tahun & 6 & 4.1 \\
\hline & $16-20$ Tahun & 1 & 0.7 \\
\hline & $21-25$ Tahun & 2 & 1.4 \\
\hline Peminatan & Gangguan Bahasa Perkembangan & 109 & 74.7 \\
\hline \multirow[t]{8}{*}{ Garap } & Gangguan Produksi Bicara & 80 & 54.8 \\
\hline & Gangguan Motorik Bicara & 65 & 44.5 \\
\hline & Gangguan Makan Menelan & 65 & 44.5 \\
\hline & $\begin{array}{ll}\text { Habilitasi Gangguan } \\
\text { Pendenoaran }\end{array}$ & 51 & 34.9 \\
\hline & $\begin{array}{l}\text { Gangguan } \\
\text { Neurogenik }\end{array}$ & 50 & 34.2 \\
\hline & Gangguan Suara & 46 & 31.5 \\
\hline & $\begin{array}{l}\text { Gangguan } \\
\text { Kelancaran }\end{array}$ & 35 & 24 \\
\hline & Gangguan Resonansi & 33 & 22.6 \\
\hline
\end{tabular}


Surakarta merupakan wilayah keanggotaan yang paling banyak. Sebagian besar responden memiliki jenjang Pendidikan Diploma III Terapi Wicara dengan pengalaman klinis kurang dari 5 tahun. Rumah sakit pemerintah merupakan tempat bekerja terapis wicara yang paling banyak. Bidang garap resonansi merupakan bidang garap yang paling sedikit diminati oleh terapis wicara. Urutan teratas bidang garap yang paling banyak diminati adalah penanganan pada kasus gangguan bahasa perkembangan.

Responden penelitian yang menggunakan NSOMT sebagai pendekatan dalam intervensi gangguan bunyi bicara adalah 124 responden. Prosentase pengguna adalah $84.9 \%$ $(n=146)$. Sebaran penggunaan NSOMT di Jawa Tengah dijelaskan pada grafik di bawah ini.

Tabel 2. Tabulasi Silang Penggunaan NSOMT sesuai Jenjang Pendidikan

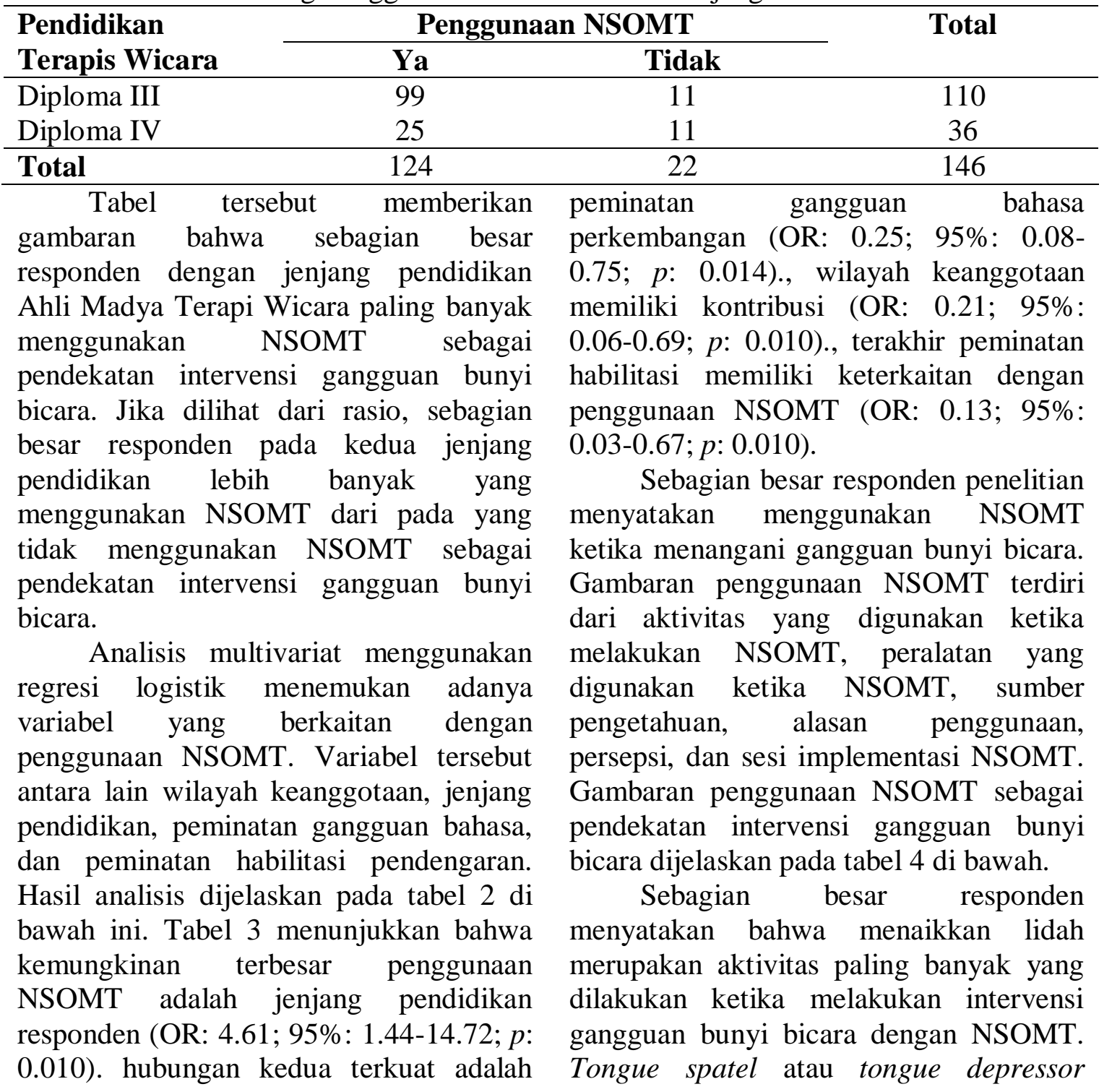


merupakan peralatan yang paling banyak digunakan responden. Pengalaman praktik klinik memberikan kontribusi yang signifikan dalam implementasi NSOMT sebagai pilihan intervensi. sebagian besar responden masih kurang yakin serta jarang menggunakan NSOMT. Pembagian sesi yang paling sering dipilih adalah melakukan NSOMT sampai batas waktu optimal lalu beralih kepada aktivitas lain. Alasan yang paling banyak dipilih responden adalah NSOMT mampu meningkatkan fungsi otot sehingga berdapak positif pada intervensi gangguan bunyi bicara.

Tabel 3. Hasil Analisis Regresi Logistik

\begin{tabular}{|c|c|c|c|c|c|}
\hline \multirow{2}{*}{\multicolumn{2}{|c|}{ Variabel }} & \multirow{2}{*}{ Adjusted OR } & \multicolumn{2}{|c|}{$95 \% \mathrm{CI}$} & \multirow[b]{2}{*}{$p$} \\
\hline & & & Lower & Upper & \\
\hline & 0.21 & 0.06 & 0.69 & 0.010 \\
\hline & Pendidikan Diploma III & 4.61 & 1.44 & 14.72 & 0.010 \\
\hline $\begin{array}{ll}\text { Peminatan } & \text { Gangguan } \\
\text { Perkembangan } & \end{array}$ & Bahasa & 0.25 & 0.08 & 0.75 & 0.014 \\
\hline \multicolumn{2}{|c|}{ Peminatan Habilitasi Pendengaran } & 0.13 & 0.03 & 0.67 & 0.015 \\
\hline
\end{tabular}

Tabel 4. Gambaran Penggunaan NSOMT di Jawa Tengah.

\begin{tabular}{|c|c|c|c|}
\hline Komponen & & $\mathrm{N}=124$ & $\%$ \\
\hline Aktivitas & Tongue elevation (lidah ke atas) & 111 & 89.5 \\
\hline \multirow[t]{9}{*}{ NSOMT } & Lip rounding (memonyongkan bibir) & 109 & 87.9 \\
\hline & $\begin{array}{l}\text { Tongue lateralization (gerakan lidah ke } \\
\text { samping) }\end{array}$ & 107 & 86.3 \\
\hline & Tongue protusion (gerakan lidah ke depan) & 106 & 85.5 \\
\hline & Open-close mouth (buka tutup mulut) & 104 & 83.9 \\
\hline & Blowing (meniup) & 103 & 83.1 \\
\hline & Lip closure (mengatupkan bibir) & 99 & 79.8 \\
\hline & Smile (tersenyum) & 92 & 74.2 \\
\hline & Lip smacking (mengecapkan bibir) & 87 & 70.2 \\
\hline & Whistle blowing (meniup peluit) & 75 & 60.5 \\
\hline \multirow[t]{8}{*}{ Peralatan } & Tongue depressor & 112 & 90.3 \\
\hline & Straw & 83 & 66.9 \\
\hline & Horn & 51 & 41.1 \\
\hline & Brushes & 79 & 63.7 \\
\hline & Balloon & 52 & 41.9 \\
\hline & Bite block/ bite stick & 50 & 40.3 \\
\hline & Whisthler & 50 & 40.3 \\
\hline & Kazoo & 32 & 25.8 \\
\hline Sumber & Ketika menjalani praktik klinik mahasiswa & 93 & 75 \\
\hline \multirow[t]{4}{*}{ Pengetahuan } & Ketika menjalani Pendidikan & 74 & 59.7 \\
\hline & Sharing dengan rekan sejawat & 66 & 53.2 \\
\hline & Mengikui seminar dan pelatihan & 58 & 46.8 \\
\hline & Belajar otodidak dari buku & 38 & 30.6 \\
\hline
\end{tabular}




\begin{tabular}{|c|c|c|c|}
\hline Persepsi Efikasi & Kurang yakin & 5 & 4 \\
\hline \multirow[t]{2}{*}{ NSOMT } & Cukup yakin & 70 & 56.5 \\
\hline & Sangat yakin & 49 & 39.5 \\
\hline Frekuensi & Jarang & 5 & 4 \\
\hline \multirow[t]{2}{*}{ Penggunaan } & Kadang-kadang & 72 & 58.1 \\
\hline & Selalu & 47 & 37.9 \\
\hline \multirow[t]{4}{*}{$\begin{array}{l}\text { Pembagian sesi } \\
\text { implementasi } \\
\text { NSOMT }\end{array}$} & $\begin{array}{l}\text { Saya melakukan NSOMT sampai dengan batas } \\
\text { pencapaian kemudian dikombinasikan dengan } \\
\text { intervensi lain meningkatkan kejelasan bicara. }\end{array}$ & 58 & 46.8 \\
\hline & $\begin{array}{l}\text { Saya membagi sesi pertemuan antara NSOMT } \\
\text { dengan intervensi lain. }\end{array}$ & 45 & 36.3 \\
\hline & $\begin{array}{l}\text { Saya menggunakan NSOMT hanya untuk } \\
\text { pemanasan sebelum intervensi artikulasi atau } \\
\text { fonologi. }\end{array}$ & 13 & 10.5 \\
\hline & $\begin{array}{l}\text { Saya menggunakan NSOMT secara eksklusif } \\
\text { dengan tidak melakukan kombinasi dengan } \\
\text { intervensi lain. }\end{array}$ & 8 & 6.5 \\
\hline \multirow[t]{5}{*}{ Alasan } & $\begin{array}{l}\text { NSOMT dapat meningkatkan fungsi otot } \\
\text { sehingga meningkatkan kejelasan bicara }\end{array}$ & 108 & 87.1 \\
\hline & $\begin{array}{l}\text { Aktivitas bicara dapat dikembangkan jika } \\
\text { kemampuan dasar artikulator baik }\end{array}$ & 84 & 67.7 \\
\hline & $\begin{array}{l}\text { NSOMT dapat meningkatkan kemampuan } \\
\text { artikulasi dan fonologi berdasarkan pengalaman } \\
\text { personal }\end{array}$ & 51 & 41.1 \\
\hline & $\begin{array}{l}\text { Aktivitas NSOMT tidak hanya berdampak pada } \\
\text { aspek motorik tetapi juga sensorik }\end{array}$ & 42 & 33.9 \\
\hline & $\begin{array}{l}\text { NSOMT memenuhi kajian ilmiah dan penelitian } \\
\text { terkini }\end{array}$ & 12 & 9.7 \\
\hline
\end{tabular}

Tabel 5. Gambaran Non Pengguna NSOMT di Jawa Tengah.

\begin{tabular}{|c|c|c|c|}
\hline \multicolumn{2}{|l|}{ Komponen } & $\mathbf{N}=\mathbf{2 2}$ & $\%$ \\
\hline \multirow{2}{*}{$\begin{array}{l}\text { Pengalaman membaca } \\
\text { literatur }\end{array}$} & Tidak pernah membaca & 12 & 54.5 \\
\hline & Pernah membaca & 10 & 45.5 \\
\hline \multirow{2}{*}{$\begin{array}{l}\text { Keyakinan efikasi } \\
\text { ilmiah NSOMT }\end{array}$} & Ragu-ragu & 14 & 63.6 \\
\hline & Yakin & 8 & 36.4 \\
\hline \multirow{2}{*}{$\begin{array}{ll}\text { Sikap } & \text { terhadap } \\
\text { NSOMT } & \end{array}$} & Tetap tidak akan menggunakan & 14 & 63.6 \\
\hline & Akan menggunakan & 8 & 36.4 \\
\hline \multirow{4}{*}{$\begin{array}{l}\text { Alasan } \\
\text { menggunakan } \\
\text { NSOMT }\end{array}$} & $\begin{array}{l}\text { Belum pernah mendapatkan pengalaman } \\
\text { personal tentang efektifitas NSOMT }\end{array}$ & 12 & 54.5 \\
\hline & $\begin{array}{l}\text { Aktivitas bicara hanya dapat } \\
\text { dikembangkan dengan bicara }\end{array}$ & 6 & 27.3 \\
\hline & NSOMT tidak memenuhi kajian ilmiah & 6 & 27.3 \\
\hline & $\begin{array}{l}\text { Hasil disuksi dengan teman sejawat, } \\
\text { dosen dan ahli lain }\end{array}$ & 6 & 27.3 \\
\hline
\end{tabular}


Responden yang tidak menggunakan NSOMT memiliki prosentase $15.1 \%$ $(\mathrm{n}=22)$. Gambaran Non NSOMT dijelaskan dengan menguraikan beberapa indikator yang terdiri dari pengalaman membaca literatur, keyakinan terhadap efikasi ilmiah, sikap terhadap NSOMT, dan alasan tidak menggunakan NSOMT. Gambaran tentang Non NSOMT dijelaskan pada tabel 5 di bawah ini. Tabel 5 memberikan gambaran bahwa sebagian responden yang tidak menggunakan NSOMT tidak pernah membaca literatur tentang penanganan gangguan bunyi bicara menggunakan pendekatan NSOMT. Sebagian besar responden masih raguragu dan sebagian akan menggunakan pendekatan NSOMT dalam penanganan gangguan bunyi bicara. Alasan paling banyak adalah belum ada pengalaman personal tentang efektifitas penanganan gangguan bunyi bicara dengan menggunakan NSOMT.

Gambaran pengetahuan responden terhadap metode intervensi gangguan bunyi bicara diukur dengan menggali frekuensi penerapan metode. Beberapa pilihan yang disediakan adalah selalu menggunakan, kadang-kadang menggunakan, tidak pernah menggunakan, dan tidak familiar. Pendekatan penanganan gangguan bunyi bicara terdiri dari tujuh belas (17) metode baik yang berbasis penanganan motorik maupun metode dengan penanganan berbasis linguistik. Penjelasan tentang rincian gambaran pengetahuan responden terhadap metode intervensi gangguan bunyi bicara dijelaskan di bawah ini

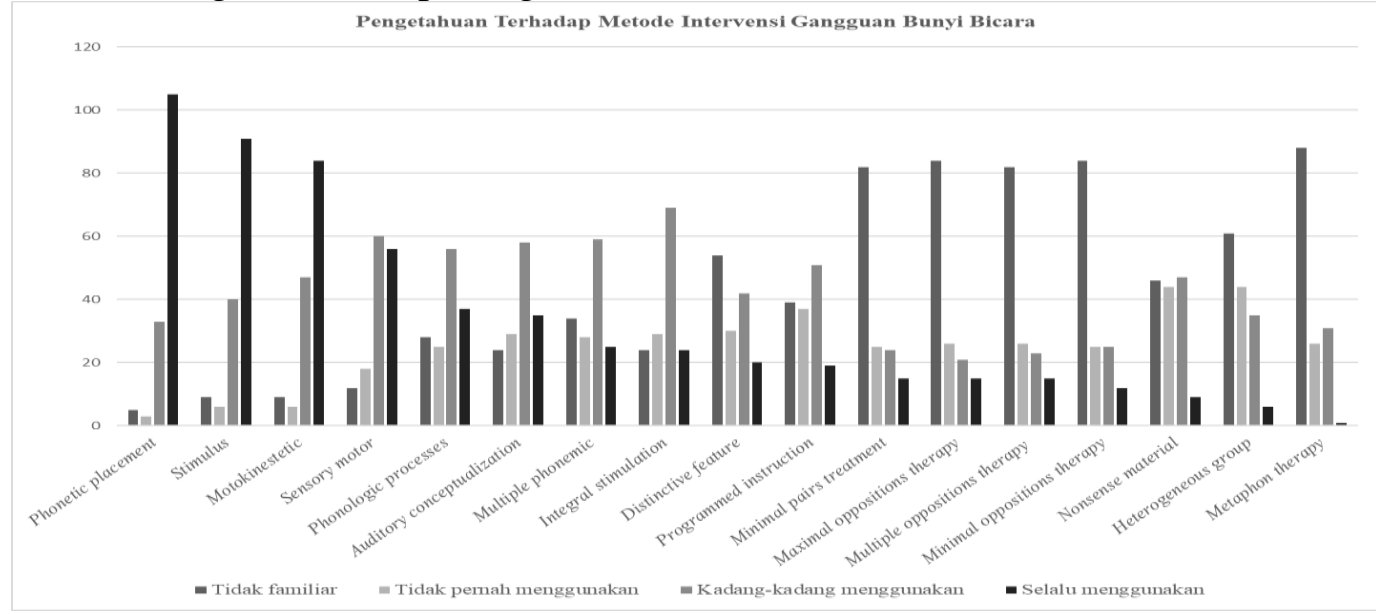

Gambar 1. Pengetahuan Responden Terhadap Metode Intervensi Gangguan Bunyi Bicara

Grafik di atas menunjukkan bahwa metode yang paling sering digunakan oleh responden penelitian adalah metode phonetic placement. Sebagian besar

responden tidak familiar dengan pendekatan metaphon therapy sebagai metode intervensi gangguan bunyi bicara. 


\section{PEMBAHASAN}

Pendekatan NSOMT dikenal sebagai pendekatan yang berbasis pada fungsi otot. Pendekatan ini memiliki efektifitas yang kuat dalam intervensi gangguan makan dan menelan (Arvedson et al., 2010; Manno et al., 2005), sehingga NSOMT menjadi salah satu teknik yang direkomendasikan dalam penanganan gangguan makan dan menelan (Dodrill \& Gosa, 2015). Meskipun dikenal efektif dalam penanganan gangguan makan dan menelan, NSOMT memiliki kontroversial ketika digunakan sebagai metode penanganan gangguan bunyi bicara. NSOMT dianggap memiliki eviden yang lemah ketika diterapkan dalam gangguan artikulasi dan fonologi (Lee \& Gibbon, 2011; Lof \& Watson, 2010; Muttiah et al., 2011).

Sebanyak $84.9 \%$ Terapis Wicara menggunakan NSOMT sebagai pendekatan dalam penanganan gangguan bunyi bicara. Hasil penelitian menunjukkan hasil yang serupa dengan hasil penelitian sebelumnya (Lof \& Watson, 2008; Thomas \& Kaipa, 2015). Hal tersebut menunjukkan bahwa NSOMT dikenal luas oleh para klinisi. Aktivitas yang sering digunakan dalam melakukan NSOMT adalah elevasi lidah. Kuat dugaan bahwa penggunaan aktivitas elevasi lidah dikaitkan dengan pembentukan fonem /1/. Fonem /1/ memiliki Point of Articulation (POA) lingual alveolar, artinya pembentukan fonem ini memerlukan pergerakan lidah ke arah gusi gigi atas. Metode tersebut merupakan bagian dari pendekatan berbasis motorik (Kuruvilla-Dugdale et al., 2018; Preston et al., 2019). Hal tersebut diduga memiliki linieritas dengan alasan penggunaan NSOMT ketika menangani gangguan bunyi bicara. Alasan terbanyak mengapa NSOMT digunakan sebagai pendekatan dalam penanganan gangguan bunyi bicara adalah adanya persepsi tentang penguatan otot. Hal ini tidak bisa dilepaskan dari kajian konseptual NSOMT yang menekankan aktivasi otot secara fisiologis dan fungsional (Clark, 2003). Sehingga patut diduga bahwa persepsi aktivitas pergerakan dalam NSOMT dikaitkan dengan pembentukan (POA). Penerapan metode dalam penanganan gangguan bunyi bicara memerlukan proses penalaran klinis yang mendalam dari setiap klinisi (Diepeveen et al., 2020).

$$
\text { Sebagian besar responden }
$$
mendapatkan informasi tentang penggunaan NSOMT untuk menangani gangguan bunyi bicara adalah ketika menjalani praktik klinik. Peran lingkungan klinis memberikan dampak besar dalam pengambilan keputusan klinis. Model dan penjelasan pembimbing, supervisor, dan rekan sejawat merupakan sumber literatur yang setiap saat bisa diakses oleh mahasiswa. Informasi yang diperoleh akan menjadi literatur yang setiap saat bisa diaplikasikan ketika mahasiswa menghadapi situasi serupa. Proses diskusi memerlukan sebuah kajian literatur berbasis EBP untuk bisa merumuskan keputusan klinis terbaik (Cirrin et al., 2010; Togher et al., 2011). Informasi tentang efektifitas NSOMT yang berasal dari buku atau jurnal tidak banyak diakses. Hal ini mengimplikasikan bahwa belum semua level EBP digunakan secara merata ketika pengambilan keputusan penggunaan NSOMT dalam penanganan gangguan bunyi bicara.

Sebagian besar responden yang tidak menggunakan NSOMT dalam penanganan gangguan bunyi bicara memiliki persepsi yang tidak konsisten 
pada penerapan NSOMT. Pemilihan sikap untuk tidak menggunakan NSOMT berbasis pada pengalaman pribadi. Pengalaman tentang penerapan NSOMT akan mengubah peta penggunaan NSOMT. Jika dikaitkan pada responden yang memilih menggunakan NSOMT dalam penanganan gangguan bunyi bicara, terdapat persamaan latar belakang penentuan sikap. Artinya pengambilan keputusan didominasi oleh pengalaman pribadi. diperlukan kajian merata pada semua level EBP sehingga tidak ada bias dalam penerapan suatu metode. Implementasi EBP tidak hanya melihat pada pengalaman melainkan pada data empiris yang kuat (Dodd, 2007). Keterbasan studi literatur dalam penarapan NSOMT menjadi isu krusial dalam penerapannya. Adanya keterbatasan literatur dan lemahnya implementasi EBP merupakan tantangan dalam pelayanan terapi wicara khususnya pada penanganan gangguan bunyi bicara. Penanganan gangguan bunyi bicara berbasis pada EBP yang yang kuat merupakan kebutuhan mendesak yang diperlukan (Baker \& McLeod, 2011). Klinisi harus mampu menentukan dan memahami level EBP dan implementasinya.

Pemahaman dan penerapan EBP dalam penanganan gangguan bunyi bicara di Jawa Tengah memiliki tantangan. Data menunjukkan adanya pemahaman yang belum merata pada semua jenis pendekatan intervensi gangguan bunyi bicara. Pemahaman tentang pendekatan intervensi memberikan kesempatan kepada klinisi untuk menentukan dan memilih variasi intervensi sesuai dengan kondisi klien. Temuan di atas menemukan bahwa phonetic placement merupakan metode yang paling familiar digunakan. Phonetic placement adalah pendekatan intervensi artikulasi yang memberikan penekanan pada penempatan titik artikulasi (Lof \& Watson, 2010). Jika dikaitkan dengan NSOMT, phonetic placement lebih mengarah pada pergerakan artikulator menuju titik artikulasi. Sedangkan NSOMT tidak memiliki batasan pergerakan spesifik. Tantangan yang paling besar adalah pemahaman yang merata pada seluruh aspek intervensi gangguan bunyi bicara.

Hasil analisis multivariat tidak menunjukkan hubungan spesifik yang berkaitan dengan NSOMT. Analisis multivariat menunjukkan bahwa peminatan bidang garap gangguan bunyi bicara tidak memiliki keterkaitan dengan penggunaan NSOMT. Temuan menunjukkan bahwa jenjang pendidikan merupakan salah satu variabel yang diduga berpengaruh pada penggunaan NSOMT. Keterbatasan literatur dan lama studi kemungkinan berpengaruh pada pemahaman literatur. Program Studi Diploma III Terapi Wicara merupakan jenjang Pendidikan dengan lama studi tiga tahun. Setiap mahasiswa menghabiskan waktu sekitar 8 bulan untuk menjalani praktik klinik. Titik berat praktik adalah penerapan metode intervensi pada suatu kasus. Dugaan tentang minimnya penggunaan literatur ilmiah menguat. Salah satu tantangan dan hambatan pelayanan klinis adalah keterbatasan sumber literatur dan penerapan EBP dalam konteks klinis. Penerapan EBP dalam penanganan gangguan bunyi bicara merupakan prasyarat yang perlu dilakukan meskipun memiliki tantangan dan hambatan dalam penerapannya (Diepeveen et al., 2020; KuruvillaDugdale et al., 2018; Preston et al., 2019). Aplikasi EBP merupakan komponen esensial dalam penanganan gangguan 
bunyi bicara. EBP memudahkan klinisi untuk menentukan dan memilih instrumen asesmen dan intervensi terbaik dalam pelayanan (Dodd, 2007). Penggunaan NSOMT memiliki tantangan pada kekuatan EBP yang ada. Narasi tentang argumentasi ketidak sesuaian NSOMT dalam penanganan gangguan bunyi bicara telah dipublikasikan (Lof \& Watson, 2010). NSOMT memiliki keterkaitan erat dengan mekanisme oral fasial. Alasan inilah yang membuat pendekatan ini memiliki hubungan dengan metode intervensi gangguan bunyi bicara berbasis motorik. Pembahasan mengenai korelasi NSOMT berkaitan dengan sistem perototan dan persarafan telah di publikasikan (Kent, 2015). Diperlukan kajian mendalam ketika mengambil keputusan dalam pemilihan pendekatan intervensi gangguan bunyi bicara.

\section{KESIMPULAN DAN SARAN}

Popularitas penggunaan NSOMT di Jawa Tengah dibuktikan dengan hampir $85 \%$ klinisi menggunannya sebagai metode intervensi gangguan bunyi bicara. Temuan ini berbanding lurus dengan temuan sebelumnya (Lof \& Watson, 2008; Thomas \& Kaipa, 2015). Isu tentang penerapan EBP dalam intervensi gangguan bunyi bicara menguat dengan fakta penelitian. Lemahnya penggunaan landasan ilmiah dalam penerapan metode NSOMT menjadi tantangan dalam penanganan gangguan bunyi bicara di Jawa Tengah. Keterbatasan penggunaan literatur merupakan barrier dalam memberikan pelayanan terbaik. Penguatan pemahaman dan implementasi EBP dalam penanganan gangguan bunyi bicara merupakan esensi penting.

Penyesuaian tindakan klinis yang berbasis pada penerapan EBP merupakan isyarat perintah klinis yang bersifat tidak tertulis (Coyle \& Leslie, 2006). Penguatan dan penambahan literatur ilmiah menjadi fokus yang penting dalam pelayanan terapi wicara di Jawa Tengah. Penguatan budaya ilmiah bisa dilakukan dengan keterlibatan klien (Cohen \& Hula, 2020). Institusi Pendidikan juga berperan besar dalam pengambangan budaya ilmiah pada klinisi (Rangamani et al., 2016). Sebagi tindak lanjut diperlukan penelusuran penerapan EBP dengan wilayah yang lebih luas seperti apa yang dilakukan oleh (Thome et al., 2020). Penelitian yang mengungkap dampak langung NSOMT pada gangguan bunyi bicara perlu dilakukan dengan pendekatan eksperimental. Penelusuran lebih luas digunakan untuk melihat bagaimana penerapan NSOMT pada penanganan gangguan bunyi bicara secara nasional.

\section{DAFTAR RUJUKAN}

Arvedson, J., Clark, H., Lazarus, C., Schooling, T., \& Frymark, T. (2010). Evidence-based systematic review: Effects of oral motor interventions on feeding and swallowing in preterm infants. American Journal of SpeechLanguage Pathology, 19(4), 321340. https://doi.org/10.1044/10580360(2010/09-0067)

Baker, E., \& McLeod, S. (2011). Evidence-Based Practice for Children with Speech Sound Disorders: Part 1 Narrative Review. Language, Speech, and Hearing Services in Schools, 42(2), 102-139. https://doi.org/10.1044/01611461(2010/09-0075)b

Cirrin, F. M., Schooling, T. L., Nelson, N. 
W., Diehl, S. F., Flynn, P. F., Staskowski, M., Torrey, T. Z., \& Adamczyk, D. F. (2010). Evidencebased systematic review: Effects of different service delivery models on communication outcomes for elementary school-age children. Language, Speech, and Hearing Services in Schools, 41(3), 233-264. https://doi.org/10.1044/01611461(2009/08-0128)

Clark, H. M. (2003). Neuromuscular Treatments for Speech and Swallowing: A Tutorial. American Journal of Speech-Language Pathology, 12(4), 400-415. https://doi.org/10.1044/10580360(2003/086)

Cohen, M. L., \& Hula, W. D. (2020). Patient-reported outcomes and evidence-based practice in speechlanguage pathology. American Journal of Speech-Language Pathology, 29(1), 357-370. https://doi.org/10.1044/2019_AJSLP19-00076

Coyle, J. L., \& Leslie, P. (2006). Evidence-Based Practice — The Ethical Imperative. Perspectives on Swallowing and Swallowing Disorders (Dysphagia), 15(4), 1-7. https://doi.org/https://doi.org/10.1044 /sasd15.4.1

Diepeveen, S., Haaften, L. van, Terband, H., Swart, B. de, \& Maassen, B. (2020). Clinical reasoning for speech sound disorders: Diagnosis and intervention in speech-language pathologists' daily practice. American Journal of Speech-
Language Pathology, 29(3), 1529_ 1549.

https://doi.org/10.1044/2020_AJSLP19-00040

Dodd, B. (2007). Evidence-Based Practice and Speech- Language Pathology: Strengths , Weaknesses, Opportunities and Threats. Folia Phoniatrica et Logopaedica, 59(1), 118-129.

https://doi.org/10.1159/000101770

Dodrill, P., \& Gosa, M. M. (2015). Pediatric dysphagia: Physiology, assessment, and management. Annals of Nutrition and Metabolism, 66(suppl 5), 24-31. https://doi.org/10.1159/000381372

Forrest, K. (2002). Are oral-motor exercises useful in the treatment of phonological/articulatory disorders? Seminars in Speech and Language, 23(1), $15-25$. https://doi.org/10.1055/s-2002-23508

Kent, R. D. (2015). Nonspeech Oral Movements and Oral Motor Disorders: A Narrative Review. American Journal of SpeechLanguage Pathology, 24(4), 763789.

https://doi.org/https://doi.org/10.1044 /2015_AJSLP-14-0179

Kuruvilla-Dugdale, M., Custer, C., Heidrick, L., Barohn, R., \& Govindarajan, R. (2018). A phonetic complexity-based approach for intelligibility and articulatory precision testing: A preliminary study on talkers with amyotrophic lateral sclerosis. Journal of Speech, 
Language, and Hearing Research, 61(9), 2205-2214. https://doi.org/10.1044/2018_JSLHR -S-17-0462

Lass, N. J., \& Pannbacker, M. (2008). The application of evidence-based practice to nonspeech oral motor treatments. Language, Speech, and Hearing Services in Schools, 39(3), 408-421.

https://doi.org/10.1044/0161$1461(2008 / 038)$

Lee, A. S. Y., \& Gibbon, F. E. (2011). Non-speech oral motor treatment for children with developmental speech sound disorders. Cochrane Database of Systematic Reviews, 10, 1-27. https://doi.org/10.1002/14651858.CD 009383.pub2

Lof, G. L., \& Watson, M. (2010). Five Reasons Why Nonspeech Oral Motor Exercises (NSOME) Do Not Work. Perspectives on School-Based Issues, 11(4), 109-117. https://doi.org/https://doi.org/10.1044 /sbi11.4.109

Lof, G. L., \& Watson, M. M. (2008). A nationwide survey of nonspeech oral motor exercise use: Implications for evidence-based practice. Language, Speech, and Hearing Services in Schools, 39(3), 392-407. https://doi.org/10.1044/01611461(2008/037)

Manno, C. J., Fox, C., Eicher, P. S., \& Kerwin, M. E. (2005). Early oralmotor interventions for pediatric feeding problems: What, when and how. Journal of Early and Intensive
Behavior Intervention, 2(3), 145159.

https://doi.org/10.1037/h0100310

Mccauley, R. J., Strand, E., Lof, G. L., Tracy, S., Tobi, F., \& Frymark, T. (2009). Evidence-Based Systematic Review: Effects of Nonspeech Oral Motor Exercises on Speech. American Journal of SpeechLanguage Pathology, 18(4), 343360.

https://doi.org/https://doi.org/10.1044 /1058-0360(2009/09-0006)

Muttiah, N., Georges, K., \& Brackenbury, T. (2011). Clinical and research perspectives on nonspeech oral motor treatments and evidence-based practice. American Journal of Speech-Language Pathology, 20(1), 47-59. https://doi.org/10.1044/10580360(2010/09-0106)

Powell, T. W. (2008). An integrated evaluation of nonspeech oral motor treatments. Language, Speech, and Hearing Services in Schools, 39(3), 422-427.

https://doi.org/10.1044/01611461(2008/039)

Preston, J. L., Leece, M. C., \& Storto, J. (2019). Tutorial: Speech motor chaining treatment for school-age children with speech sound disorders. Language, Speech, and Hearing Services in Schools, 50(3), 343-355. https://doi.org/10.1044/2018_LSHSS $-18-0081$

Rangamani, G., Coppens, P., Greenwald, M., \& Keintz, C. (2016). Collaborative Methods for Training 
Evidence-Based Practice: The Triad Model. Contemporary Issues in Communication Science and Disorders, 43(Spring), 139-153. https://doi.org/10.1044/cicsd_43_s_1 39

Ruscello, D. M. (2008). Non-speech oral motor treatment for children with developmental speech sound disorders. Language, Speech, and Hearing Services in Schools, 39, 380-391.

https://doi.org/10.1002/14651858.CD 009383.pub2

Thomas, R. M., \& Kaipa, R. (2015). The use of non-speech oral-motor exercises among Indian speechlanguage pathologists to treat speech disorders: An online survey. The South African Journal of Communication Disorders, 62(1), 112. https://doi.org/10.4102/sajcd.v62i1.8 2

Thome, E. K., Loveall, S. J., \& Henderson, D. E. (2020). A Survey of Speech-Language Pathologists' Understanding and Reported Use of Evidence-Based Practice. Perspectives of the ASHA Special Interest Groups, 5(4), 984-999. https://doi.org/10.1044/2020_persp20-00008

Togher, L., Yiannoukas, C., Lincoln, M., Power, E., Munro, N., Cabe, P. M. C., Ghosh, P., Worrall, L., Ward, E., Ferguson, A., Harrison, E., \& Douglas, J. (2011). Evidence-based practice in speech-language pathology curricula: A scoping study
Evidence-based practice in speechlanguage pathology curricula: A scoping study. International Journal of Speech-Language Pathology, 13(6), 459-468. https://doi.org/10.3109/17549507.20 11.595825

Turner, T. (2009). Developing evidencebased clinical practice guidelines in hospitals in Australia, Indonesia, Malaysia, the Philippines and Thailand: Values, requirements and barriers. BMC Health Services Research, 9(1), 235. https://doi.org/10.1186/1472-6963-9235 